\title{
Research
}

\section{Participatory Vulnerability Assessment in the Context of Conservation and Development Projects: A Case Study of Local Communities in Southwest Cameroon}

\author{
$\underline{\text { Nathalie van }}$ Vliet $^{1}$
}

\begin{abstract}
People living in landscapes of high conservation value are trapped between their dependence on natural resources to meet their development aspirations and the international pressure to conserve those resources. Although it is increasingly recognized that the conservation of some natural resources cannot happen without providing alternative livelihood solutions for local communities dependent on them, global experiences illustrate that the successful integration of conservation and development continues to be elusive. We adapted the approach based on "participatory vulnerability assessments" developed for climate change research and applied it to changes occurring in a conservation and development context. As a case study, we focused on a biodiversity hotspot in Southwest Cameroon that was recently designated a national park. We have shown that local communities believe their livelihood options will be reduced by the creation of the national park. Compensation measures such as ongoing community development plans are not yet impacting local livelihoods. Their success will only be measurable in the long term, whereas the restriction in access to the national park is already in effect. Meanwhile, new roads, and attractive prices for cash crops including cocoa, have created the opportunity for alternative sources of income that could have substantial impacts on smallholders as well as for conservation. The aim of this work was to identify risks and opportunities associated with conservation and development as a first step in improving decision making. Project activities are not implemented in isolation from the global context and are therefore not the only drivers of adaptation for local communities. One of our main findings is that new external stimuli, such as markets, may be highly influential, potentially undermining conservation and development efforts if not addressed in a properly designed adaptive process.
\end{abstract}

Key Words: exposure; integrated conservation and development; participatory vulnerability assessment; risks

\section{INTRODUCTION}

People living in landscapes of high conservation importance are trapped between their dependence on natural resources to meet their local development aspirations and the international pressure to conserve these resources with high international value. This dynamic is particularly apparent with the establishment and management of national parks and other types of protected areas, as they represent the cornerstone of most biodiversity conservation strategies (Stevens 1997, Brechin et al. 2003). In the past, some conservation initiatives have ignored the need to take into account local development aspirations to meet conservation goals and have sometimes clearly undermined human rights and livelihoods through restriction of access, displacement, or oppressive enforcement measures (Brockington 1999, Cernea 2000, Schmidt-Soltau 2005, Brockington and Igoe 2006, Cernea and SchmidtSoltau 2006, West and Brechin 1991).

However, it is increasingly recognized that conservation of some natural resources cannot be accomplished without providing alternative solutions for local communities depending on these resources for income and subsistence. In 2003, the World Parks Congress resolved that the social costs of protected-area establishment should be fully compensated (International Union for the 
Conservation of Nature 2003). The Seventh Conference of the Parties to the Convention on Biological Diversity called for an assessment of the economic and socio-cultural costs for local communities arising from the establishment and maintenance of protected areas, and an adjustment of policies to ensure that such costs and impacts are equitably compensated (Convention on Biodiversity 2004).

To conform to these international resolutions, landscape managers and conservationists are increasingly challenged with integrating social rights and development aspirations into meeting conservation goals. Organizations with the primary mission of conservation have more recently adopted forms of integrated conservation and development approaches (Campbell and Vainio-Mattila 2003), or a more explicit rights-based approach (Campese et al. 2007). Rather than a concentration on protected areas alone, a more integrated landscape approach that aims to achieve both biodiversity conservation and development outcomes is becoming more widely adopted (Wells et al. 2004). This shift toward more participatory processes to achieve conservation goals and with a landscape-level focus could be a significant step toward more equitable and successful conservation.

However, global experiences illustrate that successful "integration" of conservation and development continues to be elusive, and synergies between conservation and development do not emerge naturally (Barrett et al. 2005). Either compensation measures have no clear link to the impact of conservation on local livelihoods and, therefore, lead to a loss of resilience of local communities (Robinson and Redford 2004, Sayer and Campbell 2004, Wells et al. 2004), or they are not directly conditioned by the provision of environmental services and, therefore, lead to disastrous effects on biodiversity conservation. Other sources of failure are: the disconnection in time frames between conservation and development activities, and the lack of assessment of external risks such as markets, climate change, or the political context, that can destroy conservation and development efforts by significantly influencing local strategies to move in unpredictable directions beyond the coping range of social-ecological systems.

The concepts of resilience and vulnerability provide a useful framework for analyzing how to improve compensation measures in the context of conservation and development. The resilience knowledge domain is grounded in ecology and mathematics with a focus on theoretical models, whereas the vulnerability and adaptation knowledge domains are grounded in geography and natural hazards research. The key parameters of vulnerability and resilience are: exposure, that is, the stress to which a system is exposed; sensitivity, that is, the degree to which the system can be influenced by sources of exposure; and adaptive capacity, that is, the capacity to recover a stable state after exposure to external stimuli. A focus on "practical adaptation" is increasingly common in the field of climate change research but, to our knowledge, the term is not yet used in the field of conservation and development projects. By "practical adaptation," we mean research that investigates the adaptive capacity of a particular community to identify means of implementing adaptation initiatives (Smit and Wandel 2006). In the context of climate change, exposure is linked to natural disasters caused by climate variability, whereas in the context of conservation and development projects, community exposure is caused by changes in access to natural resources and livelihood options. The vulnerability and resilience of local livelihoods depends on people's "baseline" conditions in terms of nutrition, health, morale, and other aspects of well-being; their own efforts and strategies to reinforce their livelihoods; their access to proper support by government or civil-society institutions; and their social and political networks, including social and political capital. Participatory vulnerability assessments aim to document the ways in which the community experiences changing conditions. The focus is on conditions that are important to the community rather than those assumed to be important by researchers or other experts.

We adapted the approach proposed by Smit and Wandel (2006) developed for climate change research and applied it to changes occurring in a conservation and development context. As a case study, we focused on a biodiversity hotspot in Southwest Cameroon that was recently designated a national park. This case study includes the surrounding local communities. We used a number of participatory methods to understand sources of social exposure and sensitivity as perceived by local communities. Below, we analyze the short-term strategies developed locally to cope with change. We then discuss risks and potential new sources of 
Fig. 1. Map of the Takamanda-Mone Technical Operations Unit and Takamanda National Park.

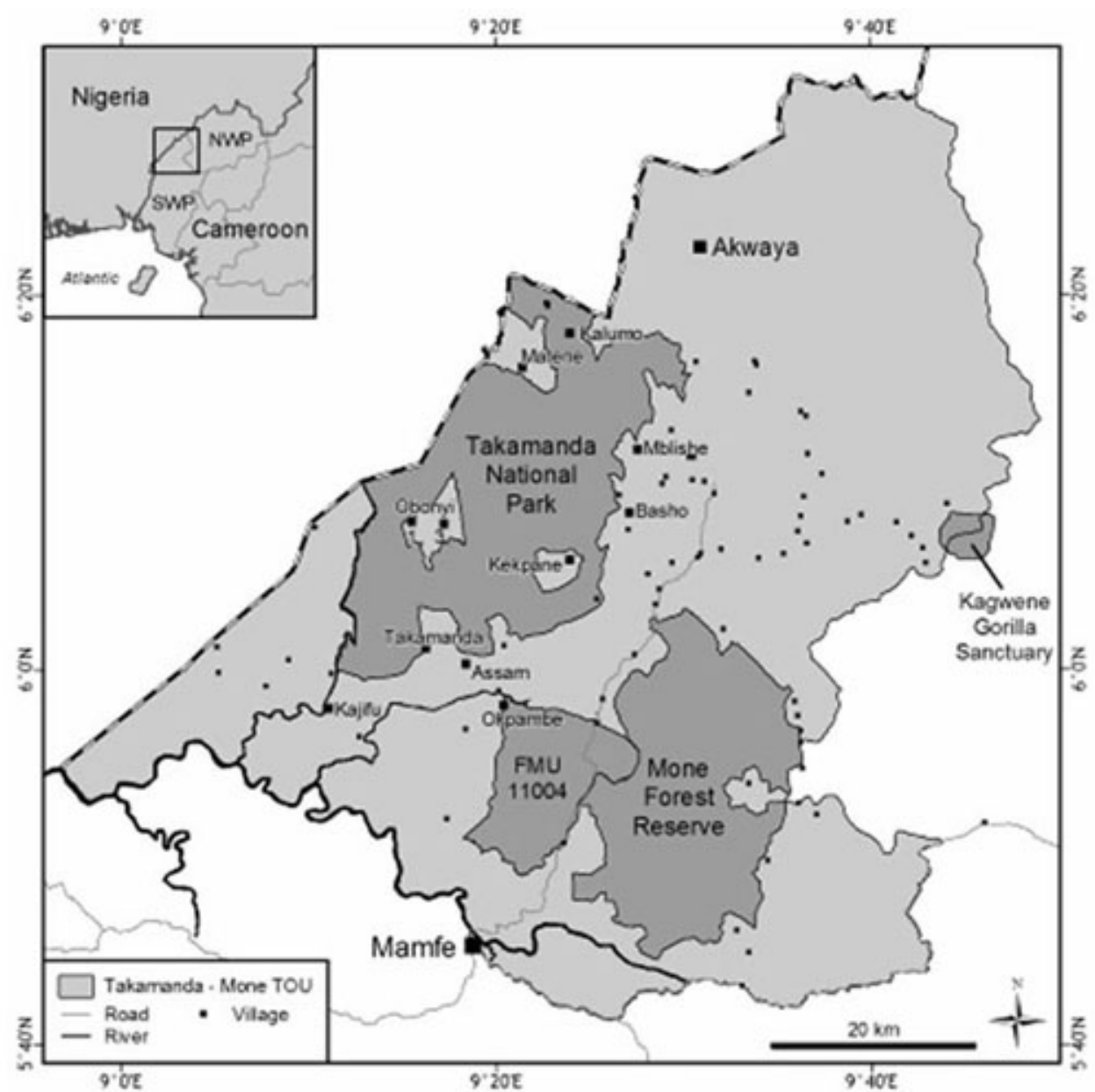

exposure or sensitivity as a basis for developing long-term adaptation strategies that could contribute to an improved integration of conservation and development.

\section{METHODS}

The recently created Takamanda National Park (69,599 ha), established in November 2008 (Ministry of Forests and Wildlife 2008), is located within the Takamanda-Mone Technical Operations Unit $(444,172$ ha) at the most northern point of Cameroon's Southwest Province (Fig. 1). The entire region is of great conservation interest because of its role as a refuge for many endemic species and its importance for watershed protection (Comiskey et al. 2003). International attention was drawn to the area largely because of the confirmed presence of the Cross River gorilla (Gorilla gorilla diehli), a subspecies of the western gorilla. The Cross River gorilla is recognized by the International Union for the Conservation of Nature (IUCN) as critically endangered, and is considered the most threatened great ape in Africa (Sarmiento 2003). At the same time, with about 15,700 inhabitants (Mdaihli et al. 2002) and the presence of four enclaves within the national park, local communities are still largely dependent on the extraction of natural resources such as non-timber forest products, timber, and wildlife for their livelihoods. 
Table 1. Sampling effort for farmer interviews in villages bordering, or enclaved within, Takamanda National Park.

\begin{tabular}{lccc}
\hline \hline \multicolumn{1}{c}{ Village name } & $\begin{array}{c}\text { Total number of } \\
\text { households }\end{array}$ & $\begin{array}{c}\text { Number of households } \\
\text { interviewed }\end{array}$ & $\begin{array}{c}\text { Sampling intensity per village } \\
(\%)\end{array}$ \\
\hline Border villages & 40 & 26 & 66 \\
Assam & 64 & 10 & 16 \\
Takamanda & 49 & 12 & 24 \\
Okpambe & 32 & 4 & 13 \\
Basho & 54 & 9 & 17 \\
Mblishe & 25 & 3 & 12 \\
Kalumo & 85 & 10 & 12 \\
Kajifu & & 10 & 16 \\
Enclaved villages & 95 & 11 & 11 \\
Obonyi 3 & 68 & 10 & 20 \\
Obonyi 1 & 91 & & \\
Matene & & &
\end{tabular}

Perceptions of exposure and sensitivity at the household level were studied in 10 villages around and enclaved in the national park (Table 1). The villages are similar in terms of tribe and language, socio-economic situation, and access to roads, markets, education, and health facilities. Detailed household surveys were conducted using structured questionnaires to a random sample of households (105 households, mean sampling effort $=20 \%$ ). Whether a household was included or not in the sampling design was determined by the toss of a coin. As only 3 days were spent in each village, if a household member was absent the day of the interview, his household was removed from the sampling design. For Assam, a small village located in the southern limit of the protected area, the sampling effort was greater than in other villages because the team visited the village on several occasions. In Assam, if a household head was absent the day of the interview, an appointment was made for another day. The interviews included information on household members, primary sources of income, current farming activities, recent changes affecting their livelihood strategies, their perceptions of the local environment, and their strategies for meeting short-term development aspirations. The field team was composed of a site coordinator, a socioeconomist, and two field assistants.

The village of Assam was chosen for additional fieldwork focused on understanding the perceptions of the community about its history and trends in their livelihoods. Various community-based methods were used to provide a framework for identifying, discussing, and scoring the most significant changes in their environment and how these had affected the use of natural resources and their livelihood strategies. The methods employed follow those described in Colfer et al. (1999) and Sheil et al. (2004), and include participatory community mapping, scoring systems, historical 
Table 2. Data collection techniques used in Assam.

\begin{tabular}{ll}
\hline \hline Technique & Description \\
\hline Initial community meetings & Meeting with chief and village elders with community \\
General village information & Existing literature \\
Household mapping & Four key informants \\
Household wealth ranking & Four key informants \\
Household profiles & Interviews to 26 household heads \\
Participatory village mapping & Focus groups (one with men/one with women) \\
Scoring exercises for land-use types and species & Focus groups (one with men/one with women) \\
Visioning & Focus groups (one with men/one with women) \\
Historical trends & Focus groups (one with men/one with women) \\
Seasonal calendar & Focus groups (one with men/one with women) \\
Traditional/local rules affecting natural resources use & Group discussion with chief and village council, individual \\
\hline
\end{tabular}

trend analyses, participatory wealth ranking, and visioning exercises. Fieldwork in Assam was carried out over several short visits between February 2008 and February 2009. Table 2 shows the type of information gathered, the methods used, and the target groups for the different activities. An initial community meeting was held with the chief, council, and other community members to provide a detailed explanation of the work objective and program, as well as to introduce the research team. This meeting was also an opportunity to agree on a suitable time and date to work with focus groups and key informants. Participatory community mapping was used to gather information about natural resources, special sites, and local perceptions within a shared geographical framework. Under the guidance of the facilitators, the participants of each focus group were encouraged to locate special features such as camps or forest paths, and land-cover types, resources, or activities such as fishing points, hunting grounds, or NTFP collection points. The household mapping and wealth ranking exercises were conducted to establish a list of all households in the settlement and to build wealth indicators, as perceived by key informants from the village (two men and two women designated by the chief). Seasonal calendar exercises were conducted to highlight the time distribution of livelihood activities carried out by community members, such as farming, NTFP collection, fishing, and hunting. Scoring exercises were used to assess the relative importance of land types and plant and animal species for different use categories including food, tools, medicine, income, recreation, construction, and tradition, at present and over the next 10 yrs. We used the "pebble distribution method" (PDM), where pebbles or other small objects are distributed over items according to their perceived relative importance. Historical trend exercises were carried out to describe life in the village $20 \mathrm{yrs}$ ago and to highlight significant changes that have led to the present situation. Visioning exercises were carried out to describe the way community members would like to see their village in $5 \mathrm{yrs}$ and then in $20 \mathrm{yrs}$. The facilitators guided the participants to ensure that the vision covered human, social, physical, and ecological assets. Traditional and local rules affecting natural resources were discussed with the village head and elders. 


\section{RESULTS AND DISCUSSION}

\section{Local Community Perceptions of Exposure and Sensitivity}

The area's recent change in status from Takamanda Forest Reserve to Takamanda National Park is seen as the main factor affecting local development aspirations. With the initial establishment of the Takamanda Forest Reserve, entry into the reserve for various activities including hunting, farming, harvesting of non-timber forest products (NTFPs), and logging, was largely unrestricted and unmanaged despite the regulations that apply to forest reserves. According to the 1994 forest law, although agricultural activities are strictly prohibited in a forest reserve, the right to use forest resources for subsistence is legally recognized (Ministry of Forestry and Wildlife 1994). On the other hand, in national parks, all human subsistence activities are forbidden unless specified in the management plan. Although the management plan for the Takamanda National Park has not yet been officially finalized, campaigns to inform communities about potential future regulations started long before the official creation of the park. Restrictions that have already been announced to local communities include a total ban on hunting, the enforced abandonment of current farms, and the immediate removal of permanent camps and temporary bush houses. In addition, the harvesting of NTFPs will be restricted to certain seasons following specific regulations concerning the harvesting areas and collection methods. Given the heavy reliance of local communities on non-timber forest harvesting activities, households fear potential future restrictions on user rights to forest resources.

Since 2007, a partnership that includes conservation, development, and governmental agencies has provided financial and technical support for community development activities as compensation measures for the creation of Takamanda National Park. These community development activities include the domestication of important NTFPs such as bush mango (Irvingia gabonensis) and eru (Gnetum africanum) to reduce the impact on wild plants and trees, the development of snail farms, and livestock production, as alternative sources of protein and income to reduce the impact of hunting on wildlife. Other activities focus on providing support for agricultural intensification and NTFP processing activities.
Although much hope is placed in the development support that the external agencies are bringing to the communities, the results of these development activities could be compromised by weak engagement from community members. Indeed, the projects developed in the communities were chosen by community members from among a pre-defined list of project proposals, thereby limiting the full participation of the community in the identification of appropriate solutions to their needs. Moreover, the activities target groups of men and women without fully taking into account gender differences in resource use and land tenure. For example, although women are more involved than men in NTFP collection activities, they are less interested in NTFP domestication because they generally do not own the land. Given the few tangible results to date, these development activities are not currently perceived by the communities to be significant livelihood strategies.

In contrast, the improvement of market access for some agricultural products is seen as a significant driver of change in people's livelihoods. In the early 1990s, a logging road connected Mamfe to Okpambe, providing access to roads at $<3 \mathrm{hrs}$ trekking distance to villages located in the southern edge of the national park (e.g., Assam, Takamanda). Later in the same decade, the building of a government-funded road that was meant to connect Mamfe to Akwaya was initiated. Although the road does not yet reach Akwaya and many bridges are still to be constructed, some villages located in the northern part of the national park are now on, or closer to, the road. An increase in prices for some cash crops has also transformed these remote areas into profitable cash-crop production zones. In particular, higher cocoa prices have made this crop highly attractive for farmers in the last $3 \mathrm{yrs}$.

\section{Coping with Change: Short-term Adaptation Strategies by Local Communities}

Discussions with focus groups in Assam highlighted the increased importance of cash-crop production at the expense of forests outside and inside the national park. According to those interviewed, only five families in Assam owned cocoa farms in 2000, whereas in 2008, 36 households $(90 \%)$ owned cocoa plantations with farm sizes ranging between 0.5 and 5 ha. Participants in the wealth-ranking exercise agreed that the main contemporary local indicator of 
relative wealth is the number and size of cocoa farms. Families that own older, and hence productive, cocoa farms are considered richer because they already benefit from the current harvest, whereas owners of young cocoa farms expect to benefit in 2-3 yrs time. The optimal strategy identified by both men and women in Assam to secure more cash income in the short term is to increase cocoa farms and other cash crops, including oil palm. In Assam, the male population expects that the most important habitat types in the next 5 yrs will be mature forests and old secondary forests outside the national park, both considered to be "bank accounts" for future farmland expansion. Their perception is that the availability of forests will decrease with the future enforcement of regulations concerning agricultural activities within the national park. The forest inside the national park will become less important for them, given that they will not benefit from it as much as they did in the past. The women expect that "farmland" and "secondary forests" will be up to five times as important as "mature forests," because the goods and services provided by the latter will be reduced by a restriction in access to forest resources in the park. This gradual shift in livelihood strategies from NTFP collection to cash-crop expansion is already translating into more forest degradation around the park. The participatory mapping exercise undertaken in Assam shows that farmland in Assam is expanding along the park boundaries. Encroachment into the park is also taking place, especially toward the eastern part of the village and inside the park along the Makone River, around camps previously used all year round for various harvesting, hunting, and fishing activities.

The findings of household interviews in the 10 villages chosen for this study provide further evidence of a continuing shift from forestry-based activities to cash-crop production, particularly in the vicinity of the national park. Interviews with farmers revealed a significant increase in the proportion of households expressing dependence on farming activities between 2001 and 2008 (z test for two proportions, $\mathrm{p}<0.0001)$. In 2001, households perceived farming and NTFP harvesting to be equally balanced in terms of contribution to their cash income, but this had changed by 2008. In 2001, about $33 \%$ of the households considered NTFP as their main source of income and $31 \%$ mentioned farming, whereas in 2008, about $62 \%$ of households perceived farming as their main source of income and only $21 \%$ relied on NTFP collection (Table 3 ).
In 2001, out of the 10 villages sampled, only Takamanda mentioned cocoa as one of their main income sources, whereas in 2008 all villages and $50 \%$ of the households considered cocoa as one of the five main income sources. Eighty-three percent of the farmers mentioned a continued increase in the number and size of farms as the strategy for achieving their short-term development goals. Of these, $90 \%$ specifically aimed to expand their cocoa farms. Only $15 \%$ reportedly rely on NTFP-related forestry activities to achieve their short-term goals, and the remaining 5\% rely on ongoing community development programs. Although $93 \%$ of the 105 farmers interviewed in the 10 villages know the boundaries of the reserve, $25 \%$ were found to have at least one farm within the reserve. In some communities, including Takamanda village, this figure is as high as $80 \%$ of those interviewed. All farmers interviewed stated that farm sizes have increased in the past 5 yrs to generate more income and food. The average farmland per farmer was 2 ha in 2001 (Mdhaili et al. 2002) and 3.4 ha in 2008. Although exact numbers are difficult to obtain because farmers fear law enforcement, many new farms have recently been established inside the boundaries of Takamanda National Park-to secure land for the future, rather than to meet urgent production needs. Some agricultural encroachment had taken place before the formal creation of the national park, in anticipation of possible compensation for the enforced abandonment of farms within its boundaries.

\section{Risks and Opportunities for Conservation and Development Associated with New Sources of Exposure and Sensitivity}

The observed shift in livelihood strategies from NTFP harvesting to cocoa production could have substantial social and economic impacts for smallholders (Fig. 2). As in other regions of Cameroon, cocoa farming appears to be a rational means to secure income and land tenure as a response to restrictions on harvesting timber and non-timber forest products (Sonwa et al. 2006). However, conflicts over land at the community level are already reported to have increased because of the general trend to increase farming and the increase in human population, especially in those villages newly connected to roads (Mdhaili et al. 2002). Although cocoa provides a highly attractive profit when prices are high, the livelihoods of local 
Table 3. Comparison of the importance of fishing, hunting, NTFP gathering, and farming, as declared by households in 2001 and 2008 (estimated as the percentage of households that declared an activity to be their main source of income).

\begin{tabular}{lcc}
\hline \hline Income source & $\begin{array}{c}2001 \\
\text { (Mdaihli et al. 2002) }\end{array}$ & $\begin{array}{c}2008 \\
\text { (this study) }\end{array}$ \\
\hline Fishing & $14 \%$ & $5 \%$ \\
Hunting & $9 \%$ & $8 \%$ \\
NTFP gathering & $33 \%$ & $22 \%$ \\
Farming & $31 \%$ & $62 \%$ \\
Other & $13 \%$ & $3 \%$ \\
\hline
\end{tabular}

people may also become more vulnerable with the increased dependence on a single cash crop. Conte et al. (1993) demonstrated that the active involvement of farmers in cash crops that rely on international markets does not make them wealthy. Although cocoa prices have significantly increased in the last $3 \mathrm{yrs}$, from U.S. \$1,500/ton in May 2005 to U.S. \$2,600/ton in February 2009 (International Cocoa Organization 2009), choosing cocoa as a primary source of income remains a risky option because prices depend on an uncertain global market, and production levels are erratic because of pest and disease attacks, predation, and a lack of capital to invest in fertilizer and pesticides (Sonwa et al. 2006). The calendar of income generation through small-scale forestry activities (mainly NTFP collection) was correlated with the peak of annual cash needs at the household level. Families usually need access to cash in September to pay school fees, and they had relied on the income generated in July and August through the harvest and sale of bush mangoes. Given the poor saving facilities in the region (e.g., savings groups, banks), the income generated by cocoa in OctoberNovember is not easily saved for the next year and tends to get spent during new year festivities. Issues of gender equity should also be noted. NTFP harvesting involves the whole family, whereas cocoa production is a male-dominated activity. Therefore, restricting NTFP collection is expected to have the greatest effects on women's incomes, creating an imbalance of income distribution within the family.

From a conservation perspective, the decrease in human activities within the park will probably be of benefit to conservation, as long as effective enforcement measures can be put in place. However, continued forest-degradation rates along the border of the national park might reduce crucial habitats for key species such as the critically endangered Cross River gorilla. This species survives in very small and fragmented populations between Nigeria and Cameroon. There are less than 300 individuals spread across 11 localities in a total range of $12,000 \mathrm{~km}^{2}$ (Oates et al. 2007). The Takamanda National Park protects less than half of the gorilla population on the Cameroonian side and some of the most important gorilla sites remain outside protected areas, such as the Awuri hills close to Assam, and part of the Atolo hills near Mbilishe (Wildlife Conservation Society 2007). This highlights the need for conservation actions to consider the landscape level and reduce leakages from inside the protected area to its immediate border. Gorilla habitats still appear connected, because genetic exchange across subpopulations has certainly occurred during the last generation (Bergl and Vigilant 2007). However, if the degradation trend persists along Takamanda National Park, gorilla habitats will continue to be lost through farming expansion, further increasing 
Fig. 2. Mapping risks and opportunities in local communities living around or inside Takamanda National Park.

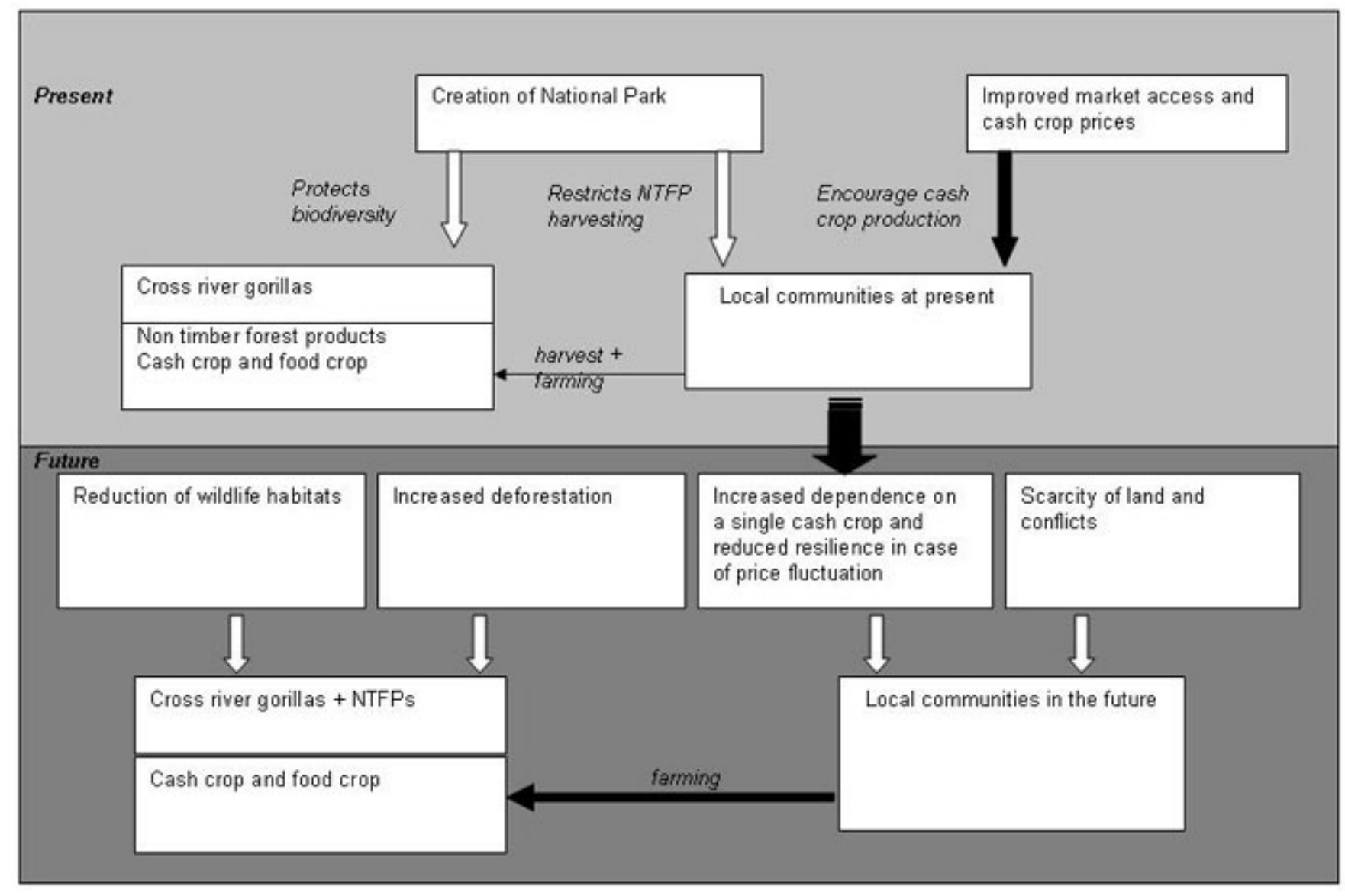

the vulnerability of this subspecies. As most cocoa requires shade, well-managed cocoa agroforestry systems outside the park could compensate for the loss of forest cover and maintain the biodiversity value of the landscape. Supporting the efforts of farmers to grow trees in their fields may help to slow the pressure on the pristine forest (Sonwa et al. 2006). Further research in the area should help to assess the potential of cocoa agroforestry systems as ex situ conservation banks, as observed by Leakey (1997) in other areas. They might also provide services such as medicine for primary health care, and fuel wood. Agricultural extension through the supply of high-yielding, diseaseresistant cocoa cultivars would also benefit local farmers and would ultimately result in higher yields/ ha. This is arguably a long-term benefit for conservation, as less forest would need to be cleared.

\section{CONCLUSIONS}

A method of participatory vulnerability assessment was used to assess local people's perceptions about how their livelihood vulnerability has changed following the designation of a national park, and the implications of this for their use of natural resources. The approach presented here employed the experience and knowledge of community members to characterize community exposure and adaptive strategies in the context of conservation and development projects. It allowed for the recognition of multiple stimuli beyond those related to the project, to include political, cultural, economic, institutional, and technological forces. In this particular case study, local communities inside and around the newly created national park perceive that their livelihood options will be reduced. 
Compensation measures such as community development plans that are financially and technically supported by external agencies are not generally impacting local livelihoods at present. Their success will only be measurable in the long term, whereas restrictions in access to the national park are already in effect. Meanwhile, new roads, and attractive prices for cash crops including cocoa, have created the opportunity for alternative sources of income that could have substantial impacts on smallholders as well as on conservation. One of the main findings from this work is that project activities are not implemented in isolation from the global context and are therefore not the only drivers of adaptation for local communities. New external stimuli, such as markets, may be highly influential and may negatively impact conservation and development efforts if not addressed in a properly designed adaptive process.

This work shows that participatory vulnerability assessments can be used to identify risks and opportunities associated with conservation and development projects. In our case study, major livelihood risks associated with the shift in livelihood strategies from NTFP harvesting to cashcrop production are the uncertainty of prices and production, the absence of savings facilities, and a gender imbalance in access to income. From a conservation perspective, the major risk is the shift of pressure on natural resources from inside the protected area to the border, with increased deforestation and destruction of key habitats in these areas.

The use of participatory vulnerability assessments within an adaptive management framework could help to increase the success of conservation and development projects by identifying diverse sources of exposure and risks throughout a project's implementation. This methodology recognizes that what is vulnerable in one period is not necessarily vulnerable, or vulnerable in the same way, in the next. Various exposures, sensitivities, and adaptive capacities interact over time. It also enables organizations to understand and incorporate the perceptions of local communities into their implementation plans, thereby ensuring more participation by the beneficiaries.
Responses to this article can be read online at:

http://www.ecologyandsociety.org/voll5/iss2/art6/responses/

\section{Acknowledgments:}

I would like to thank Forest Resources and People (FOREP) for their active involvement in field activities related to this study as well as the Landscape Mosaics project (ICRAF-CIFOR) and financial support from SDC (Swiss Agency for Development and Cooperation). Special aknowledgements to the Partnership for the Sustainable Managament of Natural Resources in Southwest Cameroon for comments on an early draft.

\section{LITERATURE CITED}

Barrett, C. B., D. R. Lee, and J. G. McPeak. 2005. Institutional arrangements for rural poverty reduction and resource conservation. World Development 33:193-197.

Bergl, R., and L. Vigilant. 2007. Genetic analysis reveals populations structure and recent migration within the highly fragmented range of the Cross River gorilla (Gorilla gorilla diehli). Molecular Ecology 16:501-516.

Brechin, S., P. Wilshusen, C. Fortwangler, and P. West, editors. 2003. Contested nature: promoting international biodiversity and social justice in the twenty-first century. State University of New York Press, Albany, New York, USA.

Brockington, D. 1999. Conservation, displacement and livelihoods: the consequences of the eviction for pastoralists moved from the Mkomazi Game Reserve, Tanzania. Nomadic Peoples 3:74-96.

Brockington, D., and J. Igoe. 2006. Eviction for conservation: a global overview. Conservation and Society 4(3):424-470.

Campbell, L. M., and A. Vainio-Mattila. 2003. Participatory development and community-based conservation: opportunities missed for lessons learned? Human Ecology 31:417-436.

Campese J., G. Borrini-Feyerabend, A. Guigner, 
and G. Oviedo, editors. (2007). "Just" conservation? What can human rights do for conservation... and vice versa?!. Policy Matters 15 July 2007, International Union for the Conservation of Nature (IUCN), Geneva, Switzerland.

Cernea, M. M. 2000. Risk, safeguards and reconstruction: a model for population displacement and resettlement. Pages 11-55 in M. M. Cernea and C. McDowell, editors. Risk and reconstruction: experiences of resettlers and refugees. World Bank, Washington, D.C., USA.

Cernea, M. M., and K. Schmidt-Soltau. 2006. Poverty risks in national parks: policy issues in conservation and resettlement. World Development 34:1808-1830.

Colfer, C. J. P., M. A. Brocklesby, D. Diaw, P. Etuge, M. Gunter, E. Harwell, C. McDoughall, N. Miyasaka Porro, R. Porro, R. Prabhu, A. Salim, M. A. Sardjono, B. Tchikangwa, A. M. Tiami, R. Wadley, J. Woelfel, and E. Wollenberg. 1999. The grab bag: supplementary methods for assessing human well-being. Center for International Forestry Research (CIFOR), Bogor, Indonesia.

Comiskey, J. A., T. C. H. Sunderland, and J. L. Sunderland-Groves, editors. 2003. Takamanda: the biodiversity of an African rainforest. SI/MAB Series Number 8. Smithsonian Institution, Washington, D.C., USA.

Conte, S., J. L. Fusillier, L. Lloga, and P. V. Nkouenkeu. 1993. Analyse économique de la filière maïs au Cameroun. Ministry of Agriculture, Yaounde, Cameroon.

Convention on Biological Diversity (CBD). 2004. Decision VII/28. Protected Areas (Articles $8(a)$ to (e)). Conference of the Parties to the Convention on Biological Diversity, Seventh Meeting. 9-20 and 27 February 2004, Kuala Lumpur, Malaysia. [online] URL: http://www.biodiv.org/doc/decisions/ COP-07-dec-en.pdf

International Cocoa Organization (ICCO). 2009. ICCO monthly averages of daily prices. [online] URL: http://www.icco.org/statistics/monthly. $\underline{\operatorname{aspx}}$

International Union for the Conservation of Nature (IUCN). Resolutions of the Fifth World Parks Congress. 8-17 September 2003, Durban,
South Africa.

Leakey, R. R. B. 1997. Agroforestry for biodiversity in farming systems. Pages 127-145 in $\mathrm{W}$. Collins and C. Qualret, editors. The importance of biodiversity in agroecosystems. Lewis, New York, New York, USA.

Mdaihli, M., K. Schmidt-Soltau, and J. S. O. Ayeni. 2002. Socio-economic baseline survey of the villages in and around the Takamanda Forest Reserve, Volumes 1 and 2. Cameroonian (MINEF) and German (GTZ) Project for the Protection of Forests around Akwaya (PROFA). Mamfe, Cameroon.

Ministry of Forestry and Wildlife (MINFOF). 1994. LOI $N^{\circ} 94 / 01$ du 20 janvier 1994 portant régime des forêts, de la faune et de la pêche. Yaoundé, Cameroon.

Ministry of Forestry and Wildlife (MINFOF). 2008. Decree No. 2008/2751/PM. 21 November 2008, Yaoundé, Cameroon.

Oates J., J. Sunderland-Groves, R. Bergl, A. Dunn, A. Nicholas, E. Takang, F. Omeni, I. Imong, R. Fotso, L. Nkembi., and L. Williamson. 2007. Regional action plan for the conservation of the Cross River Gorilla (Gorilla gorilla diehli). Conservation International, Arlington, Texas, USA.

Robinson, J. G., and K. H. Redford. 2004. Jack of all trades, master of none: inherent contradictions among ICD approaches. Pages 10-34 in T. O. McShane and M. P. Wells, editors. Getting biodiversity projects to work: towards better conservation and development. Columbia University Press, New York, New York, USA.

Sarmiento, E. E. 2003. The Cross River gorilla: the most endangered gorilla subspecies. Primate Conservation 19:65-72.

Sayer, J., and B. Campbell. 2004. The science of sustainable development. Cambridge University Press, Cambridge, UK.

Schmidt-Soltau, K. 2005. The environmental risks of conservation related displacements in central Africa. Pages 282-311 in I. Ohta and Y. D. Gebre, editors. Displacement risks in Africa. Trans Pacific, Melbourne, Australia. 
Sheil D. R., K. Puri, I. Basuki, M. van Heist, M. Wan, N. Liswanti, R. Mustofa, A. Sardjono, I. Samsoedin, K. Sidiyasa ,C. E. Permana, E. M. Angi, F. Gatzweiler, B. Johnson, and A.Wijaya. 2004. Exploring biological diversity, environment and local people's perspective. CIFOR, Bogor, Indonesia.

Smit B., and J. Wandel. 2006. Adaptation, adaptive capacity and vulnerability. Global Environmental Change 16:282-292.

Sonwa J. D., S. Weise, A. Adesina, M. Tchatat, 0. Ndoye, and D. Endamana. 2006. Adaptations of cocoa and coffee farmers' communities in the heart of remnant pristine forest of east Cameroon to institutional changes. Pages 339-347 in Proceedings of the International Union of Forest Research Organizations (IUFRO) Landscapse Ecology Conference. 26-29 September 2006, Locorotondo, Bari, Italy.

Stevens, S., editor. 1997. Conservation through cultural survival: indigenous people and protected areas. Island Press, Washington, D.C., USA.

Wildlife Conservation Society (WCS). 2007. The proposed Takamanda National Park: Cross River gorilla surveys. February-May 2007, KfW Bankengruppe, Frankfurt, Germany.

Wells, M. P., T. O. McShane, H. T. Dublin, S. O'Connor, and K. H. Redford. 2004. The future of integrated conservation projects: building on what works. Pages 397-422 in T. O. McShane and M. P. Wells, editors. Getting biodiversity projects to work: towards better conservation and development. Columbia University Press, New York, New York, USA.

West, P. C., and S. R. Brechin, editors. 1991. Resident peoples and national parks: social dilemmas in international conservation. University of Arizona Press, Tucson, USA. 